\title{
Peace Negotiations Cannot Be Held Forever: Breaking the Deadlock in the Armenia-Azerbaijan Conflict
}

\author{
* ADA University, Azerbaijan \\ ORCID No: 0000-0002-6352-0180 \\ ** Khazar University, Azerbaijan \\ ORCID No: 0000-0003-4653-270X
}

FARID SHAFIYEV* and VASIF HUSEYNOV**

\begin{abstract}
The Armenia-Azerbaijan conflict resolution process had experienced insurmountable deadlock due to the failure of the peace negotiations brokered by the Organization for Security and Cooperation in Europe (OSCE) Minsk Group, co-chaired by Russia, France, and the United States since the mid-1990s. The so-called Velvet Revolution of Armenia in 2018 was unable to deliver any progress, although a breakthrough was expected of, and promised by, the new leadership of the country. This, coupled with the constant provocations of the military and political leaders of Armenia, aggravated the conflict and led to the outbreak of an almost full-scale war on September 27, 2020. The war changed the status quo and created an environment for the negotiated resolution of the conflict following the establishment of a humanitarian ceasefire in Moscow. Armenia's subsequent violations of the ceasefire regime by targeting Azerbaijani civilians have, however, demonstrated that peace is likely to remain an inaccessible dream of the region's people in the short to medium term.
\end{abstract}

Keywords: Azerbaijan, Armenia, Nagorno-Karabakh, South Caucasus

Insight Turkey 2020

Vol. 22 / No. 4 / pp. 99-109

Received Date: 15/10/2020 • Accepted Date: 08/11/2020 • DOI: 10.25253/99.2020224.07 


\section{Introduction}

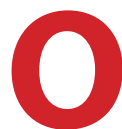

$n$ the threshold of the dissolution of the Soviet Union at the end of the 1980s, a violent dispute broke out between Soviet Armenia and Azerbaijan, caused by a call from Armenian nationalists to carve out the Nagorno-Karabakh autonomous region of Azerbaijan and unify it with Soviet Armenia. After the break-up of the Soviet Union, Armenia launched a full-scale military operation against Azerbaijan in 1992-1994, which resulted in the occupation of almost twenty percent of Azerbaijan's internationally recognized territory. The occupied territories included the Nagorno-Karabakh region and seven adjacent districts of Azerbaijan.

In 1993, the UN Security Council adopted four resolutions -822, 853, 874 , and 884- demanding the withdrawal of Armenian troops from the occupied Azerbaijani territories. The resolutions reconfirmed the Nagorno-Karabakh region and the other occupied territories as part of the Republic of Azerbaijan. The military hostilities persisted, however, after the adoption of these resolutions and a ceasefire was only reached in May 1994, through the mediation of Russia, in Bishkek, Kyrgyzstan.

The peace negotiations between the two parties to the conflict were entrusted to the mediation of the Conference for Security and Cooperation in Europe (CSCE), which was later renamed the Organization for Security and Cooperation in Europe (OSCE), in line with a regional arrangement under Chapter VII of the UN Charter. Since the mid-1990s, the Minsk Group of the OSCE, an international mission including eleven states and co-chaired by the United States, Russia, and France, has coordinated the conflict resolution process and has offered a number of settlement formulations in that time.

The so-called "Basic Principles," also known as the "Madrid Principles," presented by the co-chair states of the Minsk Group in November 2017 in Madrid, Spain, held the highest potential for an effective and peaceful resolution. ${ }^{1}$ According to this document, the territories surrounding the Nagorno-Karabakh region are supposed to return to Azerbaijan's control. Nagorno-Karabakh will be given an interim status and provided with guarantees for security and self-governance, while its final legal status will be determined later by a legally binding expression of will (i.e., a plebiscite).

The international efforts to reach a resolution, however, failed to deliver a breakthrough owing to the consistent deconstructive moves of the Armenian government. Being interested in the prolongation of the status quo and consolidation of control over the occupied territories of Azerbaijan, the Armenian leaders refused to implement the principles. This aggravated the situation on the frontline, sporadically causing violent escalations (e.g., in April 2016), and minimized hopes for a peaceful settlement. 
The change of government in mid2018 in Armenia initially generated marked optimism for an eventual breakthrough. This was caused not only by signals from the highest level of the Armenian government, but also by the relatively peaceful environment on the front line. Unfortunately, it was soon clear that Armenia's new government, headed by Prime Minister Nikol Pashinyan, was abusing this process to consolidate its domestic control, as it soon revitalized extremist approaches relating to Armenia's claim to the occupied territories of Azerbaijan. This policy approach, bolstered by the belligerent rhetoric of Armenia's military top brass, destroyed any possibility for a negotiated resolution and led the process toward the grievous escalation on September 27, 2020.

\section{The False Promise of Armenia's 2018 Regime Change}

In the aftermath of the so-called Velvet Revolution of 2018, which brought Nikol Pashinyan to power in Armenia, a degree of optimism arrived at the negotiating table. In contrast to his predecessors, Prime Minister Pashinyan is not of Karabakh origin and is not associated with the war of the early 1990s. This was part of the reason that he was expected to show more constructivism with regard to the peace negotiations.

There were, indeed, a number of positive developments at the beginning of Pashinyan's rule. In late 2018, the leaders of Azerbaijan and Armenia

\section{According to recently} declassified information, the leaders of the two countries were also in private communication through the initiative of the Armenian side

agreed on the establishment of a telephone hotline between the military commanders for the first time and, in January 2019, they agreed to take concrete measures to "prepare populations for peace." According to recently declassified information, during this time the leaders of the two countries were also in private communication through the initiative of the Armenian side. ${ }^{2}$ It has been leaked that Armenia's Prime Minister, Nikol Pashinyan, had indirectly communicated his desire to resolve the conflict through negotiations that took place secretly in an unspecified European country. This happened against the backdrop of a substantial decline in the number of casualty-causing incidents to just a handful in 2019. ${ }^{3}$

The new situation in the conflict, on the one hand, indicated the importance of the political will for de-escalation and, on the other hand, generated hope and favorable conditions for further agreements and an eventual breakthrough. Those expectations, unfortunately, did not become reality, as an abrupt volte-face of Prime Minister Pashinyan caused a dramatic de- 


\section{Having caused dramatic}

\section{frustration amongst}

Azerbaijanis, such

provocations, coupled with

growing militarization on

the Armenian side, left no

chance for the resolution of

the conflict at the negotiation

table cess only after consultation with and consent from all parties. This formula implied that, given some progress in the talks, both communities of the Nagorno-Karabakh region -Armenian and Azerbaijani- would become involved, as clarified by the Minsk Group Chairman in a statement issued on September 15, 1992.

Armenia's military leadership demonstrated an even more deconstructive and markedly belligerent position. Addressing a meeting of the Armenian diaspora in New York in March 2019, Armenia's Defense Minister, Davit Tonoyan, declared that Yerevan would use the formula "new war for new territories" instead of the formula "peace in exchange for territories" proposed by the mediators. According to him, this strategy "will rid Armenia of this trench condition, the constant defensive state, and will add the units which may shift the military actions to the territory of the enemy." 5 Tonoyan made this statement immediately after the OSCE-mediated meeting of the Prime Minister of Armenia with the President of Azerbaijan in Vienna, which resulted in a joint statement on the need to create a favorable environment for peace and the adoption of results-oriented steps in the negotiation process to find a peaceful settlement to the conflict.

An extremist position was also taken by the Armenian Prime Minister who, in August 2019, in his address at the opening ceremony of the Pan-Armenian games that were held illegally in Khankandi, part of the 
[United Nations] Security Council resolutions." This caused particular concern in Armenia as the resolutions of the UN Security Council, adopted in 1993, demand the immediate withdrawal of Armenian military forces from the occupied territories of Azerbaijan.

A month later, in yet another provocative move, the Armenian side held an inauguration ceremony, with Prime Minister Pashinyan present, for the new so-called president of the local regime in the city of Shusha in occupied Nagorno-Karabakh -a place of deep cultural significance to Azerbaijanis. Having caused dramatic frustration amongst Azerbaijanis, such provocations, coupled with growing militarization on the Armenian side, left no chance for the resolution of the conflict at the negotiation table.

Against this background, Azerbaijan began to express more loudly its dissatisfaction with the international mediation, thereby underscoring the potential ramifications of Armenia's provocations for peace and security in the entire region. On July 6, in one of his last media appearances before the Tovuz clashes, Azerbaijani President Ilham Aliyev openly criticized the international mediators in the negotiations, declaring that the peace process had become "meaningless." ${ }^{10}$ These concerns did not receive much international attention, which encouraged Armenia to organize systemic attacks against Azerbaijan on both the state border and in the occupied Nagorno-Karabakh region.

\section{Tovuz Clashes: Harbinger of a Bigger War}

On July $12-15,2020$, the conflict between Armenia and Azerbaijan escalated into a major military confrontation along the state border straddling Azerbaijan's Tovuz and Armenia's Tavush regions. The clashes, involving heavy artillery as well as aerial drones, resulted in the deaths of several military personnel and civilians along with the destruction of infrastructure in the border region. The attack - directly along the state border between the two rival South Caucasus neighbors- was a deliberate move by the Armenian side to lay the ground for the involvement of the Moscow-led CSTO in the conflict.

Notably, any hostilities in the Karabakh region itself or the surrounding Armenian-occupied areas do not fall under the jurisdiction of the alliance owing to the status of this area as part of Azerbaijan's internationally recognized territories. In an attempt to invoke Article 4 of the CSTO Charter, which designates an attack on a member state as an attack against all members, Armenia's Foreign Minister, Zohrab Mnatsakanyan, held a phone conversation with CSTO Secretary General Stanislav Zas. A few hours after their talks, the secretary general announced an emergency meeting of the organization; however, that meeting was soon postponed indefinitely, for unknown reasons.

A plan to sever the connection between Azerbaijan and Europe was also assumed by some observers as 
part of the motivation leading to the July clashes. ${ }^{11}$ Importantly, Azerbaijan's Tovuz district, where the clashes took place, is a region that hosts major energy pipelines (the Baku-Tbilisi-Ceyhan oil pipeline and the Southern Gas Corridor) and transportation routes (the Baku-Tbilisi-Kars railway and the East-West Transport Corridor) connecting Azerbaijan with Europe through Georgia and Turkey. Any instability in this part of Azerbaijan would deal a serious blow to its connection with its Western partners, with overarching consequences for both sides. Therefore, the potential role of some third parties who oppose the rise of Western influence in the South Caucasus in the recent escalation on the border is also an assumption deserving serious attention.

Although the clashes in Tovuz calmed down quickly, an increased militarization of Armenia was observed in its aftermath. This was reflected in both the inflow ${ }^{12}$ of arms to Armenia from third countries and the country's formation of a militia of 100,000 female and male volunteers aged up to $70 .{ }^{13}$ There were reports about the shipment of tons of weapons from Russia to Armenia in the wake of the Tovuz escalation. The Azerbaijani government was not convinced by Russia's explanation that it was merely "construction materials" inside the aircraft that passed through the complex transportation routes, as the shortest route via Georgia was unavailable thanks to the principled position of the Georgian government.
The day after the agreement on the humanitarian ceasefire, Azerbaijan was shocked by a missile attack by the armed forces of Armenia against a densely-populated civilian settlement in Ganja, Azerbaijan's second largest city, at 2 AM

This was accompanied by the resumption of the illegal settlement of Armenians based in foreign countries in the occupied territories of Azerbaijan. A day after the catastrophic explosion in Beirut, Lebanon, on August 4, 2020 Arayik Harutyunyan, the leader of the occupying forces in Karabakh, declared that they were ready to receive 100-150 Armenian families. ${ }^{14}$ Later, speaking at an August 25, 2020 meeting devoted to assistance programs to Lebanese-Armenians, Harutyunyan declared that his administration would "welcome and provide housing to all [...] compatriots who wish to move" to Karabakh. ${ }^{15}$ Armenia's illegal settlements in the occupied territories, which violate the Geneva Convention of 1949 , aim at the consolidation of control over the region and the creation of a fait accompli for future negotiations.

These were the major signals of an upcoming war between the two countries. On September 19, 2020 President Aliyev of Azerbaijan 
The war in the military field stretched over into the information space as well. From the outset of hostilities, the Armenian side disseminated a stream of disinformation for various purposes. Most importantly, attempting to invoke the collective defense article of the CSTO, Armenia accused Azerbaijan of targeting an Armenian fighter jet inside Armenian territory. Outraged by the political support of Turkey for Azerbaijan, they claimed that Azerbaijan had used a Turkish F-16 aircraft to target Armenia's SU25. However, these attempts proved futile, as the CSTO did not react to them, and the hostilities remained local and fell short of evolving into a regional war between Russia and Turkey.

According to the official statistics provided by the respective sides as of October 14, the Armenian side has lost more than 500 military servicemen while Azerbaijan has lost at least 43 civilians (no information about military casualties was reported by Azerbaijan's defense ministry). In its counteroffensive, Azerbaijan has been able to liberate some strategic positions in its occupied territories including the Jabrail region, the Hadrut, and Suqovushan (Madagiz) settlements, and several small villages.

The international calls for an immediate ceasefire and a return to negotiations did not affect the conflict until October 9, when the foreign ministers of Azerbaijan and Armenia met in Moscow at the initiative and through the mediation of the Russian government. As a result of the ten-
There was a belief that any military move by Azerbaijan to liberate its occupied territories would entail a Russian backlash that Baku would not dare face

hour talks, the sides agreed on the establishment of a humanitarian ceasefire and the restart of negotiations on the basis of "Basic Principles." The agreement also included a clause on the format of the negotiations that reaffirmed the existing format and thus rejected the demands of the Armenian government about the representation of the occupying regime in Karabakh in the negotiations.

The day after the agreement on the humanitarian ceasefire, Azerbaijan was shocked by a missile attack by the armed forces of Armenia against a densely-populated civilian settlement in Ganja, Azerbaijan's second largest city, at 2 AM. The attack was perpetrated from the territory of Armenia, that is, not from the occupied territories of Azerbaijan, and killed at least ten civilians while leaving many others, including women and children, wounded.

\section{Conclusion}

The protraction of the peace negotiations between Armenia and Azerbaijan against the backdrop of the 


\section{The active phase of the}

war was supposed to end

on October 10, 2020 in

accordance with the Moscow

agreement between the

foreign ministers of Armenia

and Azerbaijan mediated by

the foreign minister of Russia absence of international pressure on Yerevan to abide by international law and the resolutions of the United Nations Security Council had apparently assured the Armenian leaders that their control over the occupied territories would remain unchallenged in the years to come. Relying on the security assurances within the CSTO, not only did the country start to mock the negotiations, but it also sought to consolidate the status quo and build new settlements in the occupied territories. There was a belief that any military move by Azerbaijan to liberate its occupied territories would entail a Russian backlash that Baku would not dare face.

This was the reason why the Armenian government challenged Azerbaijani people's limits of the patience through constant provocations. By shouting "Karabakh is Armenia, period," denying the existence of any document on the negotiating table and thus rejecting the Madrid principles, holding a so-called inauguration ceremony for the leader of the occupying regime in Shusha, a historic
Azerbaijani town, planning to move the "capital" of the occupational regime to Shusha, adopting a military doctrine announcing "new war for new territories," and so on, the Armenian government derailed the negotiations and caused new escalations.

The second Karabakh war came hard on the heels of these developments. Emboldened by its defense pact with the CSTO and the military deliveries from Russia in the wake of the Tovuz clashes, Armenia attacked the positions of the Armed Forces of Azerbaijan with the apparent objective of implementing Defense Minister Davit Tonoyan's "new war for new territories" strategy. Quite contrary to Armenia's expectations, thus far Russia has refused to become militarily involved in the conflict, referring to the fact that the clashes did not occur in the territories of Armenia and, as such, are not covered by the collective defense commitments of the CSTO.

The active phase of the war was supposed to end on October 10, 2020 in accordance with the Moscow agreement between the foreign ministers of Armenia and Azerbaijan mediated by the foreign minister of Russia. However, the attack by the armed forces of Armenia against the civilian settlement of Ganja city in Azerbaijan and the subsequent violation of the humanitarian ceasefire by the Armenian side demonstrate that the ceasefire is fragile and it will not be possible to achieve peace unless Armenia abandons its territorial claims and accepts the supremacy of international law. 


\section{Endnotes}

1. "Statement by the OSCE Minsk Group Co-Chair Countries," Organization for Security and Cooperation in Europe, (July 10, 2009), retrieved October 13, 2020, from https://www.osce.org/mg/51152.

2. Eynulla Fatullayev, "Secret Talks between the Envoys of Nikol Pashinyan and Ilham Aliyev [Тайные переговоры между эмиссарами Никола Пашиняна и Ильхама Алиева]," Наqqin. az, (September 24, 2020), retrieved October 13, 2020, from https://haqqin.az/news/190193.

3. "The Nagorno-Karabakh Conflict: A Visual Explainer," International Crisis Group, (September 27, 2020), retrieved October 13, 2020, from https:// www.crisisgroup.org/content/nagorno-karabakh-conflict-visual-explainer.

4. Vasif Huseynov, "New Hope for a Breakthrough in the Nagorno-Karabakh Deadlock?," (April 6, 2020), retrieved October 13, 2020, from https:// www.cacianalyst.org/publications/analytical-articles/item/13611-new-hope-for-a-breakthrough-in-the-nagorno-karabakh-deadlock? html.

5. Ayaz Rzayev, "Azerbaijan-Armenia Clashes Put an End to Cautious Optimism," Middle East Institute, (July 23, 2020), retrieved from https://www. mei.edu/publications/azerbaijan-armenia-clashes-put-end-cautious-optimism.

6. Joshua Kucera, "Pashinyan Calls for Unification Between Armenia and Karabakh," Eurasianet, (August 6, 2020), retrieved October 13, 2020, from https://eurasianet.org/pashinyan-calls-for-unification-between-armenia-and-karabakh.

7. Abdul Kerimkhanov, "What Did 2019 Mean in Terms of Karabakh Conflict?," Azernews, (December 30, 2019), retrieved October 13, 2020, from https://www.azernews.az/karabakh/160259. html.

8. Rahim Rahimov, "Russian Foreign Minister Reignites Conflict Debate in Armenia, Azerbaijan," Eurasia Daily Monitor, (May 4, 2020), retrieved October 13, 2020, from https://jamestown.org/ program/russian-foreign-minister-reignites-conflict-debate-in-armenia-azerbaijan/.

9. “Foreign Minister Sergey Lavrov's Remarks and Answers to Questions at a Roundtable Discussion with the Participants of the Gorchakov Public Di- plomacy Fund in the Videoconference Format, Moscow," Ministry of Foreign Affairs of the Russian Federation, (April 21, 2020), retrieved October 13, 2020, from https://www.mid.ru/en/foreign_policy/news/-/asset_publisher/cKNonkJE02Bw/content/id/4103828.

10. "Ilham Aliyev Attended the Inauguration of Modular Hospital for Treatment of Coronavirus Patients Opened in Khatai District of Baku," (July 6, 2020), retrieved October 13, 2020, from https:// en.president.az/articles/39491.

11. Brenda Shaffer, "Armenia-Azerbaijan Conflict Poses Threat to European Energy Security," Foundation for Defense of Democracies, (July 17, 2020), retrieved October 13, 2020, from https://www. fdd.org/analysis/2020/07/17/armenia-azerbaijan-conflict-energy-security/.

12. Esmira Jafarova, "Russian Military Shipments to Armenia - a Dangerous Escalation?," Euractiv, (August 31, 2020), retrieved October 13, 2020, from https://www.euractiv.com/section/azerbaijan/opinion/russian-military-shipments-to-armenia-a-dangerous-escalation/.

13. Ani Mejlumyan, "Armenia to Create Nationwide Civilian Militia," Eurasianet, (September 25, 2020), retrieved October 13, 2020, from https:// eurasianet.org/armenia-to-create-nationwide-civilian-militia.

14. Anzhelika Zakaryan, "Artsakh Is Ready to Receive Lebanese-Armenians [Unguunu umuunnuuun t nunnılutı thnulumumhuנtnpl]," Civilnet, (August 5, 2020), retrieved October 13, 2020 from https:// www.civilnet.am/news/2020/08/05/Ungurunümunnuuun-t-nunntuti-thpulumumhmjtnhu/ 392053.

15. "Two Lebanese-Armenian Families Settle in Artsakh," Asbarez, (August 25, 2020), retrieved October 13, 2020 from http://asbarez.com/196423/ two-lebanese-armenian-families-settle-in-artsakh/.

16. "President Ilham Aliyev: If the Armenians Do Not Give Up Their Ugly Plans, They Will Face Very Serious Consequences," Azertag, (September 19, 2020), retrieved October 13, 2020 from https:// azertag.az/en/xeber/President_Ilham_Aliyev_If_ the_Armenians_do_not_give_up_their_ugly_ plans_they_will_face_very_serious_consequences-1589715. 


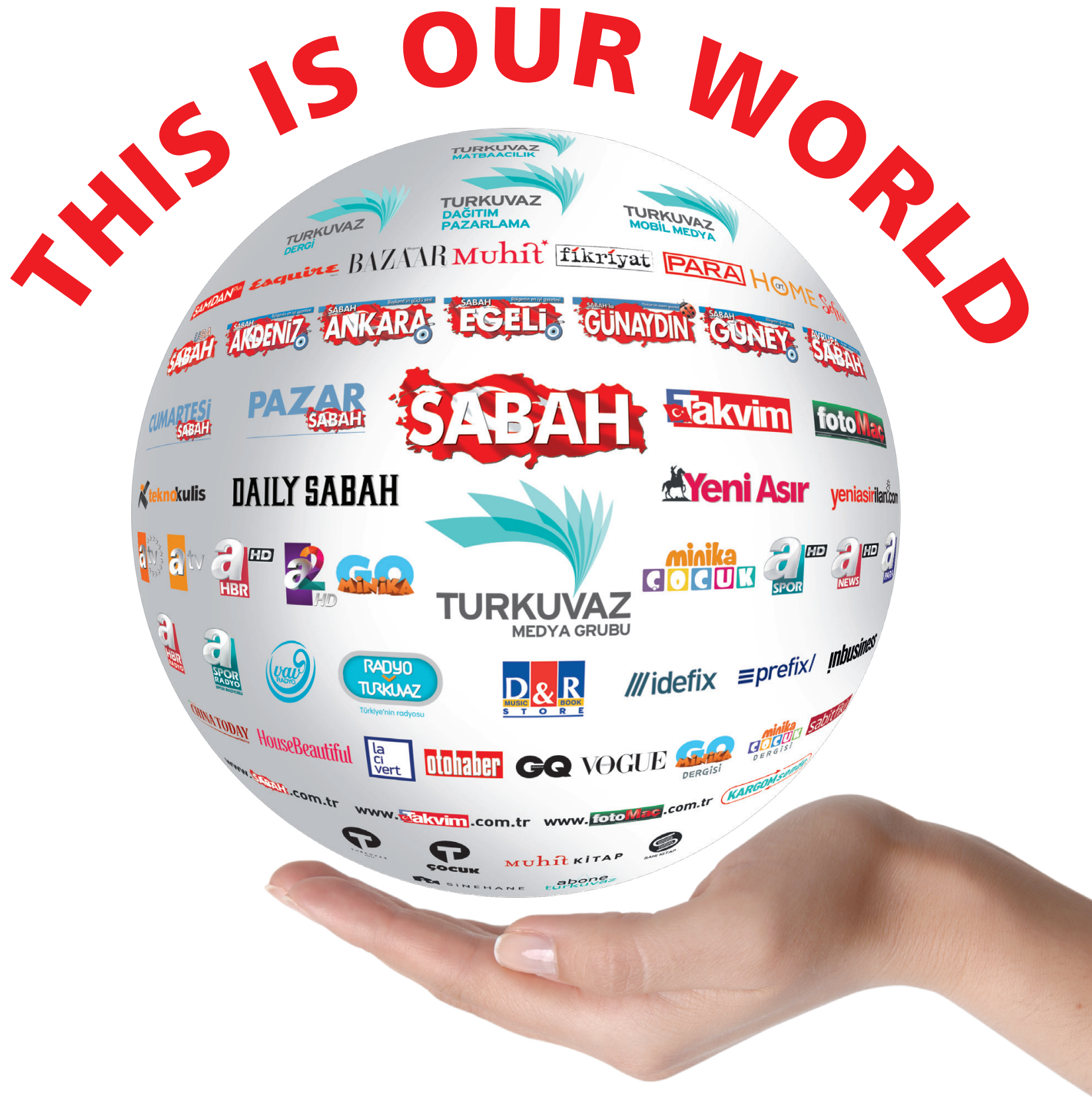

Turkuvaz Media Group is the leading group of companies which deals with broadcasting, publishing and distribution activities in Turkey. Most reputable national and international magazines, best selling local and national newspapers and prestigious tv channels create the most powerful synergy in Turkish media.

The opportunity to utilize this power for your advertisements is in your hands.

Why not use it? 


politicstoday.org

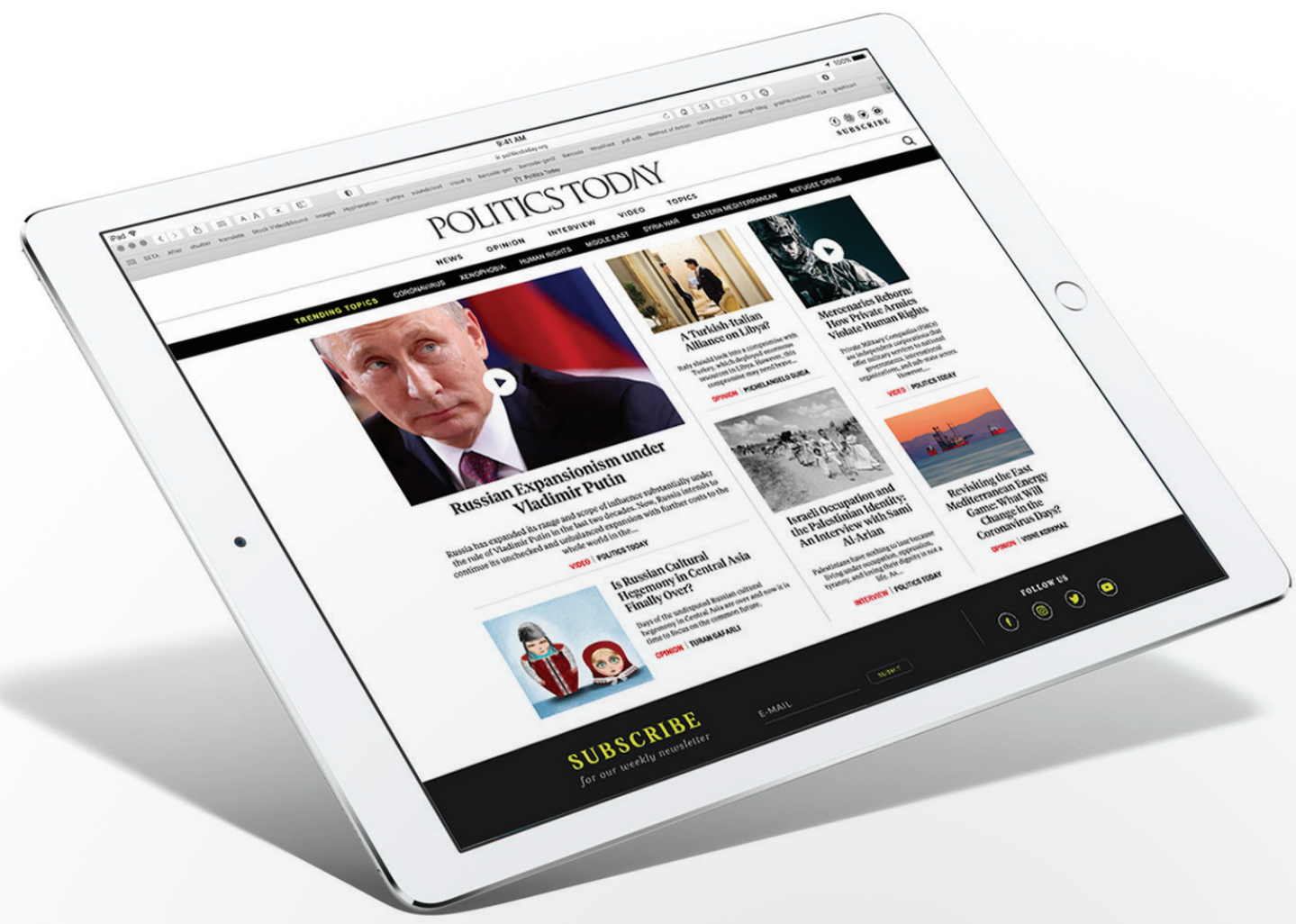

Are you concerned with the contemporary world,

where human rights are violated, human dignity is trampled, international order is indifferent to any principle or value, and the might silences the right?

Then, follow and join Politics Today in its endeavor to understand and analyze the changing nature of international politics.

\section{POLITICS TODAY}

